\title{
CROP AND LIVESTOCK INSURANCE AS RISK MANAGEMENT INSTRMENTS IN POLISH AGRICULTURE COMPARED TO THE EU REGULATIONS
}

\author{
POISTENIE RASTLÍN A ZVIERAT \\ AKO NÁSTROJ MANAŽMENTU RIZÍK \\ V POLSKOM POLNOHOSPODÁRSTVE \\ V POROVNANÍ S PREDPISMI EÚ
}

\author{
Izabela LIPIŃSKA*
}

\section{Introduction}

Production activity in agriculture is to large extent unpredictable, which is due to its nature and being dependent on numerous external factors that an agricultural producer has got a limited or no influence on at all. The uncertainty of production is accompanied with the lack of stability of farmers' income. In order to mitigate the consequences of losing income it seems necessary to apply specific legal measures. The paper analyses the issues connected with risk management in agricultural production illustrated with the example of insurance contracts, especially agricultural insurance covering crop and livestock insurance. They are designed to compensate the losses suffered by farmers as the result of the occurrence of an adverse event. The events may result from, for instance, an unexpected change of the weather (such as drought, heavy rain, flood, hail) or the occurrence of pests

\section{Abstract (EN)}

Risk management in agricultural production is currently one of the objectives of the Common Agricultural Policy. In order to secure the income of agricultural producers certain forms of support at both the EU and the national levels have been established, including making subsidized crop and livestock insurance contracts. The paper aims at determining the condition of the mentioned insurance contracts in Poland and answering the question to what extent a certain insurance system implemented by the national legislator serves its purpose as a risk management instrument. The conclusion is that as for compulsory contracts, since their scope is limited compared to the EU regulations, they are still not an effective measure, which partly results from the application of ad hoc support by the State. The legislative solutions in that regard should, hopefully, bring some positive developments.

\section{Keywords (EN)}

crop insurance, livestock insurance, risk management, Common Agricultural Policy, damage in the production or animal diseases ${ }^{(1)}$. It refers obviously only to those events which affect the course of production, its profitability, excluding single, accidental events.

Making an attempt to define risk management itself, it needs to be stressed that it is a conscious and organized set of actions aimed at predicting possible accidental adverse events and losses which result from these events, at designing and implementing specific procedures which make it possible to minimize occurrence of the above-mentioned events ${ }^{(2)}$. The

MOŹDZIOCH M. - PLOCH A. 2010. Climatic changes and crop insurance. Insurance news. p. 133-150. ISSN 0137-7264.

(2) KWIECIEŃ I. 2010. Insurance in managing risk in a business activity. C.H. Beck, Warszawa, p. 45. ISBN: 978-83-255-1461-7; OLKIEWICZ A. 2015. Risk in agricultural activity and insurance instruments of reducing it. Annals of the Polish Association of Agricultural and Agribusiness Economists. Vol XVII, No 2, p.

\section{Abstrakt (SK)}

Manažment rizík $\mathrm{v}$ polnohospodárskej produkcii je momentálne jedným z cielov Spoločnej polnohospodárskej politiky. Za účelom zabezpečenia príjmu pre polnnohospodárskych producentov, boli zavedené určité formy podpory na úrovni EÚ, aj na národnej úrovni vrátane dotácií na uzatváranie poistných zmlúv na rastliny a zvieratá. Príspevok sa zameriava na určenie podmienok pre spomínané poistné zmluvy v Polsku a tiež na zodpovedanie otázky: "do akej miery slúži systém poistenia implementovaný na národnej úrovni svojmu účelu ako nástroj manažmentu rizík". Záver pre povinné zmluvy je, že nakolko ich rozsah je obmedzený v porovnaní s predpismi EÚ, stále nie sú efektívnym opatrením, čo z časti vyplýva aj z ad hoc aplikácie pomoci zo strany štátu. Legislatívne riešenie $v$ tomto smere by malo prispiet $\mathrm{k}$ pozitívnemu vývoju.

\section{Klúčové slová (SK)}

poistenie rastlín, poistenie zvierat, manažment rizík, Spoločná polnohospodárska politika, poškodenie produkcie

\footnotetext{
Poznań University of Life Sciences, Poland
} 
proper managing helps to protect assets, incomes, obligations, human resources and, at the same time, to maintain the highest efficiency with the lowest possible costs of protection $^{(3)}$. An important role in managing is played by suitable legal regulations ${ }^{(4)}$. While trying to define risk in agricultural production it is essential to stress that it is a set of actions which enable running an agricultural activity with the awareness of risk which may appear ${ }^{(5)}$. The awareness should be combined with the willingness to select suitable risk management measures, which requires both the actions taken on the part of the legislator relating to preparing proper selection of legal measures and on the part of agricultural producers who should select the measures corresponding to the direction of production.

Although the issues raised in the paper are not new, they are still valid. They have already been discussed in connection with various fields, such as economics, mathematics or management. The reference books usually discuss insurance in terms of the role it plays in risk management and they attempt to determine its desired model ${ }^{(6)}$. The most significant legal works dealing with the subject include Risikomanagement im Agrarsektor Der Völker und europarechtliche Rahmen ${ }^{(7)}$, by J. Martinez or Risk management in agriculture: What role for policy in the new Common Agricultural Policy? by Jesus An$\operatorname{ton}^{(8)}$. What needs to be stressed is that legal issues have so

176-182. ISSN 1508-3535.

(3) ŁYSKAWA K., ROJEWSKI K. 2015. Categories of threats and risk in agricultural production- especially in plant production. In: Plan production insurance in Poland. (Editor KACZAŁA M., ROJEWSKI K.), Poltext, Warszawa, p. 43.

(4) LIPIŃSKA I. 2016. Crop and livestock insurance as a production risk management instrument in Poland and the EU. In: The agrarian issue. Legal and economic questions. (Editor Litwiniuk P.), p. 217-233.

(5) KACZAEA M. - ŁYSKAWA K. 2008. Effective insurance in managing a farm. Insurance news. No 1/2, p. 36. ISSN 0137-7264.

(6) SZEKELY C. - PALINKAS P. 2009. Agricultural risk management in the European Union and USA. Studies in Agricultural Economics. No 109, p. 55-72. ISSN (electronic) 2063-0476; HAMULCZAK M., STAŃKO S. 2008 (editors). Price risk management and the ways to stabilize the income of agricultural producers, Institute of Agricultural and Food Economics National Research Institute Warszawa. ISSN 2392-3458; HARDAKER B. J., HUIRNE R. B. M., ANDERSON J. R., LIEN G. 2004. Coping with Risk in Agriculture. CA BI Publishing, Wallingford, p. 1-332 ISBN 0-85199-831-3; EC 2001. Risk Management Tools for EU Agriculture. Working Document, Agriculture Directorate-General: Economic analyses, forward studies, evaluation, [online]. [cit. 2016.10.07]. Available at: http://ec.europa.eu/agriculture/publi/ insurance/text_en.pdf; Mußhoff O., Hirschauer N. 2010. Modernes Agrarmanagement Vahlen. 4. Auflage. Munchien. ISBN 978-3-8006-3684-6.

(7) MARTINEZJ. 2012. Risikomanagement im Agrarsektor Der Völker und europarechtliche Rahmen. In. FRENTRUP, M., THEUVSEN L., EMMANN C. H. Risikomanagement in Agrarhandel und Lebensmittelindustrie, Clenze: Agrimedia. p. 75-93. ISBN: 978-386263-080-6

(8) ANTON J. 2015. Risk management in agriculture: What role for policy in the new Common Agricultural Policy? In: Research Handbook on EU Agriculture Law (Editor MCMAHON J. A., CARDWELL M. N.). Edward Elgar Publishing, Cheltenham. p. 62-85. ISBN 978-1-78195-461-4. far been raised to a much smaller extent and they often accompany economic discussions, which can be exemplified by the reports drafted by the Organisation for Economic Cooperation and Development (OECD) ${ }^{(9)}$. Moreover, special credit should be given to the report of the European Parliament drafted in 2016 under the guidance of T. GarcíaAzcárate: Research for Agri Committee - State of Play of Risk Management Tools Implemented by Member States During the Period 2014-2020: National and European Frameworks. The report discusses the issues of risk management in selected Member States putting particular emphasis on legal and economic solutions of the insurance in question.

\section{Objects and Methods}

The aim of the paper is to determine the condition of agricultural insurance in Poland and to attempt to determine the extent to which a certain crop and livestock insurance system introduced by the national legislator lends itself as a risk management instrument. The paper intends also to assess the legal regulations adopted in Poland in the context of the EU legal framework. Additionally, it is essential to show the direction in which the legislation is going while preparing amendments to the basic legal regulations in that respect.

Due to its nature, the paper is based on a dogmatic analysis of normative texts and a descriptive method. It also refers to Polish and foreign books on the subject.

\section{EU's Concept of Risk Management}

The European Union raised the issue of risk management in agriculture for the first time in 2001 when the European Commission analysed its particular instruments. The work resulted in drafting the Communication from the Commission to the Council of 9 March 2005 on Risk and Crisis Management in Agriculture ${ }^{(10)}$. In its preamble, the Commission stressed that farmers should take responsibility for risk management, which used to be mitigated by the policy supporting both the market and prices. Simultaneously, as the result of the reform of the CAP at that time, income support was separated in main production sector, which was supposed to enable farmers to safely plan the production depending on economic and agronomic criteria. That form of support, at the same time, was supposed to help to adjust production to climatic and sanitary risk as well as to market trends.

The Commission proposed three types of risk management instruments. The first type related to insurance against natural disasters, including adverse climatic conditions and animal diseases. It was supposed to be an alternative to further

(9) OECD 2000. Income Risk Management in Agriculture. Paris; OECD. 2001. Risk Management Tools for EU Agriculture. Working Document, Agriculture Directorate-General: Economic analyses, forward studies, evaluation, European Commission; KIMURA S., ANTON J., LETHI C. 2009. Managing Risk in Agriculture: A Holistic Approach. OECD. Paris.

(10) COM (2005) 74, 9 March 2005. [cit. 10.10.2012]. 
payment of compensation from public funds for the losses at the EU, national and regional level. Some countries, in order to incentivize farmers to take out insurance against such events, envisaged bonuses for farmers paid on account of losing income as a result of a natural disaster or a disease ${ }^{(11)}$. Another group of instruments included mutual funds, which were supposed to enable risk division among the producers who wanted to take responsibility for risk management. The legislator wanted to create a system accredited by a Member State in compliance with its national law which would allow associated farmers to take out common insurance ${ }^{(12)}$. By means of the fund the compensations were paid to the farmers (associated in the fund) who suffered economic losses as a result of the occurrence of events specified in law.

The last option was connected with providing basic insurance coverage against income crises.

All mentioned instruments were designed to compensate for the consequences of the CAP reform and to replace simultaneously applied extraordinary ad hoc measures. They constituted the core of Council Regulation (EC) No 73/2009 of 19 January 2009 Establishing Common Rules for Direct Support Schemes for Farmers under the Common Agricultural Policy and Establishing Certain Support Schemes for Farmers, Amending Regulations (EC) No 1290/2005, (EC) No 247/2006, (EC) No 378/2007 and Repealing Regulation (EC) No $1782 / 2003^{(13)}$.

Currently, following another reform of the CAP, the list of risk management instruments in agricultural production is specified under Article 36 of Regulation (EU) No 1305/2013 of the European Parliament and of the Council of 17 December 2013 on Support for Rural Development by the European Agricultural Fund for Rural Development (EAFRD) and Repealing Council Regulation (EC) No 1698/2005 ${ }^{(14)}$. The list includes a) financial contributions to premiums for crop, animal and plant insurance against economic losses to farmers caused by adverse climatic events, animal or plant diseases, pest infestation, or an environmental incident; b) financial contributions to mutual funds to pay financial compensations to farmers, for economic losses caused by adverse climatic events or by the outbreak of an animal or plant disease or pest infestation or an environmental incident c) an income stabilisation tool, in the form of financial contribu-

(11) Kwota gwarantowana przez UE w ramach takiego środka na rolnika oraz wsparcie krajowe/regionalne nie powinny przekraczać 50\% ogólnego kosztu premii przewidzianej dla ubezpieczenia. Systemy ubezpieczeń od klęsk żywiołowych muszą odpowiadać wytycznym dotyczącym pomocy państwa w dziedzinie rolnictwa UE i wymogom kategorii zielonej (green box) WTO. The guaranteed amount by the EU within the mentioned framework as well as the national/regional support should not exceed $50 \%$ of the total premium for the insurance. Insurance schemes for natural disasters must comply with guidelines on state aid in the agriculture of the EU and the requirements of the green box (green box) of the WTO.

(12) JANOWICZ-LOMOTT M. - ŁYSKAWA K. 2009. Agricultural insurance subsidized by the state - Polish experience and EU recommendations - summary, Insurance News. No 2, p. 138. ISSN 0137-7264.

(13) OJ L 30, 31.1.2009, p. 16.

(14) OJ L 347, 20.12.2013, p. 487-548. tions to mutual funds, providing compensation to farmers for a severe drop in their income.

The EU legislator sets out directly neither the form of contract nor the rules to form the funds, leaving these issues to the Member States to decide. The legislator lays down only the rules of financing those instruments, which is to be discussed further in the paper.

\section{Financing agricultural insurance from the EU funds}

The legislator, in order to incentivize farmers to manage risk, provided for support on account of crop, animal and plant insurance against losses caused by adverse climatic conditions, animal and plant diseases, pest infestation or an environmental incident. The losses mean any additional costs incurred by a farmer as a result of exceptional measures taken by the farmer with the objective of reducing supply on the market concerned or any substantial loss of production. What needs to be noticed is that only active farmers are entitled to use the support in question, pursuant to Article 9 of Regulation No. 1307/2013(15).

Pursuant to Article 37 of Regulation No 1305/2013, the support is granted only for insurance contracts which cover for loss caused by an adverse climatic event, or by an animal or plant disease, or a pest infestation, or an environmental incident or a measure adopted in accordance with Directive 2000/29/EC to eradicate or contain a plant disease, or pest $^{(16)}$. The losses, however must exceed $30 \%$ of the average annual production of the farmer in the preceding three-year period or a three-year average based on the preceding fiveyear period. The yearly production for a given farmer can be calculated by means of biological indexes, equivalent yield loss indexes or weather indexes. The calculation method used shall permit the determination of the actual loss of an individual farmer in a given year. The indexes are established at the farm, local, regional or national level.

As for animal diseases, the financial compensation in question can be granted only in respect of diseases mentioned in the list of animal diseases established by the World Organisation for Animal Health or in the Annex to Decision 2009/470/EC ${ }^{(17)}$

Farmers are eligible to be granted support if an adverse event has been previously recognised by a Member State's competent authority. A State can in advance establish criteria on the basis of which such formal recognition shall be deemed to be granted.

The support in question is limited to $65 \%$ of the value of the insurance premium due and, as it was indicated above, if the loss exceeds 35\% of the average annual production of a farmer. It does not mean, however, that lower number does not qualify as a loss. The legislator assumes, however, that it stays within regular and common economic losses occur-

(15) Regulation (EU) No 1307/2013 of the European Parliament and of the Council of 17 December 2013 establishing rules for direct payments to farmers under support schemes within the framework of the Common Agricultural Policy and repealing Council Regulation (EC) No 637/2008 and Council Regulation (EC) No 73/2009, OJ L 347, 20.12.2013, p. 608.

(16) OJ L 169, 10.7.2000, p. 1.

(17) OJ L 155, 18.6.2009, p. 30-45. 
ring in a business activity and should be covered by farmers themselves.

The Member States should also ensure that no overcompensation of damages occurs as a result of the combination of Union, national and private compensation schemes.

\section{Agricultural insurance in the context of Polish law}

Agricultural insurance falls into the category of economic insurance. Broadly speaking, insurance covers any property interest which should be understood as certain economic value or any kind of goods protected by law ${ }^{(18)}$. From the substantive perspective, an insurance agreement has been defined as a nominate agreement in Articles 805-828 of the Civil Code ${ }^{(19)}$. Pursuant to Article $805 \& 1$ of the Civil Code, by the contract of insurance, the insurer undertakes within the scope of his enterprise's activity to render specified performance when an accident envisaged in the contract occurs and the insuring party undertakes to pay a premium. Thus the insurer undertakes to incur risk of paying a certain amount of money in the event of an accident specified in a contract. An accident means a future and uncertain event beyond the control of an insuring party the occurrence of which results in a specific harm. The event needs to bear specific features in order to be approved by an insurance company as the event leading to the obligation to give insurance cover.

Economic insurance constitutes quite a wide and diversified group of insurance. The main criterion is the obligation on the part of a farmer to make an insurance contract. Compulsory insurance includes third party liability insurance of farmers and the compulsory insurance of buildings included in an agricultural farm insurance against fire and other accidents and crop insurance. The obligation to make the first two contracts is included in the Act on 22 May 2003 on Compulsory Insurance, the Insurance Guarantee Fund and the Polish Motor Insurers' Bureau (hereinafter referred to as the Act on Compulsory Insurance $)^{(20)}$. The other types are regulated by the Act of 7 July 2005 on Subsidies for Crop and Livestock Insurance (hereinafter referred to as the Agricultural Act) $)^{(21)}$.

The measures under the Agricultural Act are of a specific legal structure. The legislator has provided for insurance premium subsidies from public funds as well as established specific rules for making and performing contracts of compulsory crop insurance against the consequences of accidents and the terms and conditions for designated subsidy to cover part of compensation for losses caused by drought (Article 1 of the Act $)^{(22)}$. It needs to be stressed here that the Act is addressed to agricultural producers but the payments are given

(18) ORLICKI M. 2011. Insurance contract. In: Law of obligations specific matters. (Editor PANOWICZ-LIPSKA J.) CH BECK Warszawa, p. 801-814. ISBN 978-83-255-2550-7.

(19) ACT of 23 April 1964 THE CIVIL CODE. Polish Journal of Law 1964, No. 16, item 93, with subsequent amendments.

(20) Polish Journal of Law 2013, item 392 with latest amendments.

(21) Polish Journal of Law 2015, item 577.

(22) NAWRACALAJ. 2010. Commercial Insurance Law. Commentary on legal regulations on the insurance market. Wolters Kluwer, Warszawa, vol. I, p. 1282. to insurance companies since the payments constitute part of insurance premium owed to the insurer.

What needs to be stressed, in respect of the measures included in the above-mentioned legal acts, is that the Agricultural Act serves as lex specialis in relation to the provisions of the Civil Code. The Civil Code just outlines the legal and functional framework for the contract which can be modified in the course of making it and does not give the contract any obligatory character. The legislator, however, provides for a compulsory character of an agricultural contract. At the same time, however, the construction of an agricultural contract differs from the compulsory insurance model laid down in Articles 1-22 of the Act on Compulsory Insurances, which can be exemplified by the way the contracts regulate risk. The Agricultural Act sets out a sort of risk catalogue and the insurance obligation is deemed to be fulfilled if the insurance covers at least one of risks set out in the Act. The Act on Compulsory Insurance, in turn, always specifies the scope of risk ${ }^{(23)}$. The Agricultural Act covers the situation where a farmer, due to the refusal of an insurer, failed to make a contract whereas the Act on Compulsory Insurance does not cover such a situation (Article 5(2) of the Act on Compulsory Insurance). What is more, a special role relating to agricultural insurance has been given to a competent minister of agriculture who is entitled to supervise the making of contracts and applying subsidies in connection with those agreements. Additionally, pursuant to Article 10(1) of the Agricultural Act, the minister can also check if the contracts comply with the Act and laws on public finances. The above-mentioned features reflect the legislator's approach towards agricultural contracts and subsidies relating to those contracts.

\section{Public support for insurance}

Pursuant to Article 1(1) of the Agricultural Act, the State grants premium subsidies for the insurance of: crop, corn, rape, turnip rape, hop, tobacco, field vegetables, fruit trees and bushes, strawberries, potatoes, sugar beets or leguminous plants, from sowing or planting to harvesting, against the risk of losses caused by hurricane, flood, heavy rain, hail, thunder, ground fall, avalanche, draught, negative effects of winter time and spring frost. An insurance contract may cover all or selected by an agricultural producer types of risk, which may lead to losses in the main crop. The crop by-products, for example straw, leaves of root crops are not covered.

Budget subsidies cannot exceed $65 \%$ of the premium. By 30 November of each year the Council of Ministers sets out by means of the regulation the amount of premiums for the following year. In order to do that such factors as the crop area which is to be covered by insurance and budget act guidelines need to be taken into account. The subsidies to 1 ha in 2016 as well as the planned subsidies for 2017 amount to $65 \%{ }^{(24)}$.

(23) ORLICKI M. 2011. Compulsory insurances, Wolters Kluwer, Warszawa, p. 155-176. ISBN 978-83-264-3553-9.

(24) \& 1 Regulation of the Council of Ministers of 30 November 2015 on the amount of premium subsidies for livestock insurance in 2016, Polish Journal of Law 2015, item 2024. 
The legislator also sets out a maximum limit to tariff rates the amount of which cannot exceed, in relation to the insurance of crop, corn, swede rape, turnip rape, potatoes or sugar beets, $3,5 \%$ of insured sum of crops. If the types of risk are divided, the insured sum of a given type of crop refers to all types of risk. As for the insurance of winter rapeseed, field vegetables, hop, tobacco, fruit trees and bushes, strawberries or leguminous plants - the maximum limit cannot exceed $5 \%$ of the insured sum. Again, if the types of risk are divided, the insured sum of a given type of crop refers to all types of risk (Article 5(2) of the Agricultural Act). What it means in practice is that if an insurance company sets the rate at the level of $5 \%$ of the insured sum of strawberries, with subsidy at the level of $65 \%$ this year, the actual premium paid by a farmer will amount to $2,75 \%$, and the balance will be paid to the insurer by the State.

It needs to be stressed that insurance companies are allowed to set tariff rates at a higher level than indicated above. Then, the subsidies will be granted on condition that those rates do not exceed $6 \%$ of the insured sum. As for the insurance of field vegetables as well as fruit trees and bushes premium subsidies will be granted in the amount of $5 \%$ of the insured sum. Other crops than those listed in the Act are not eligible for premium subsidies.

\section{Crop insurance}

The national legislator has envisaged both compulsory and voluntary crop insurance ${ }^{(25)}$. As for the compulsory one, the reason justifying the interference of the State is vulnerable nature of agriculture, which is often prone to risk. Additionally, it reflects the farmers' attitude towards insurance and risk management. The farmers are not willing to incur additional production-related costs connected with taking out a policy and, as a result, they refrain from making contracts. At the same time, since they operate in an unstable environment, they count on the state support in the future. To avoid such situations, the legislator has introduced an obligation to make insurance contracts. It needs to be stressed, however, that the obligation relates only to selected types of risk and insurance objects. As for voluntary contracts, because of their nature, the parties have the freedom to shape them.

Pursuant to Article 10c (1), the farmer who was granted direct payments, as defined by the regulations on payments within direct support scheme, is obliged to make an obligatory crop insurance contract against the losses caused by flood, draught, hail, negative effects of winter time and spring frost. The insurance obligation is fulfilled if, starting from 1 July of the year following the date where the farmer was granted direct payments, within 12 months, at least $50 \%$ of the planted area is covered by an insurance policy against at least one of above-mentioned types of risk.

A farmer, to fulfil the statutory obligation, makes a contract for 12 months with a selected insurance company provided the company has made an agreement with a competent Minister of Agriculture on support or with other company provided it runs insurance activity connected with the required

(25) NAWRACAŁAJ. 2010. Commercial Insurance Law. Commentary on legal regulations on the insurance market. Idem. 1307. insurance.

The liability of a given insurance company in respect of compulsory crop insurance starts 14 days following taking out crop insurance against losses caused by flood, drought, hail and spring frost. As for negative effects of winter time, the liability starts on the day of making a compulsory insurance contract but such a contract must be made not later than on 1 December.

Pursuant to the statutory terms and conditions of compulsory insurance, an agricultural producer who fails to make a compulsory insurance contract is obliged to pay the equivalent of EUR 2 per 1 ha calculated on the basis of an average exchange rate announced by the National Bank of Poland.

\section{Livestock insurance}

The Act in question, as it has been mentioned before, regulates also the issues relating to livestock insurance. The livestock includes cattle, horses, goats, poultry or pigs and is not subject to compulsory insurance contracts. The losses relating to this type of production, however, may be substantial and, thus, they may jeopardize the financial liquidity of a given farm, which can be exemplified by the fallen stock. Farmers, however, usually can extend the cover by buying additional clauses. The clauses may refer to the extension of insurance cover by additional types of risk and costs relating to the loss of reproduction usefulness, foetal death and loss of offspring in horses and cows, costs of destruction of animal carcases (collection, transport and processing animal carcases) of insured cattle and working horses, which were incurred by the animal owners or losses caused in milk production.

Under Article 3(1) of the Agricultural Act the support is granted only to the insurance premiums for above-mentioned livestock insurance against risk of only those losses which were caused by hurricane, flood, heavy rain, hail, thunder, ground fall, avalanche, and obligatory slaughter ordered by a veterinary doctor. The contract may cover all or selected by an agricultural producers types of risk. The public support for insurance premiums, however, must not exceed $65 \%$ of the premium for one animal.

\section{Proposed amendments to the agricultural insurance sys- tem}

Currently, work is going on the amendment to the Act on Crop and Livestock Insurance ${ }^{(26)}$. The amendment aims at enhancing the insurance system and providing agricultural producers with wider access to subsidized crop insurances by means of introducing increased tariff rates.

Proposed amounts of support cannot exceed 65\% of the crop insurance premium and the livestock insurance premium. Therefore, $35 \%$ is going to be covered by a farmer on the condition that maximum amounts of insured sums are not higher, which means that insurance companies cannot exceed tariff rate of crop insurance against all types of

(26) Bill of amending the Act on Crop and Livestock Insurance and the Stamp Duty Act, Form 469, https://legislacja.rcl.gov.pl/projekt/12281402. [cit. 10.10.2012]. On November 15th the Senate approved the mentioned Act. Still it has to be signed by the President of Poland. The Act will come into force on January lst, 2017. 
risk amounting to $9 \%$ of the insured sum. Varied rates refer to crops cultivated on agricultural lands of $5^{\text {th }}$ and $6^{\text {th }}$ class. Their value does not exceed, respectively, $12 \%$ and $15 \%$ of crop insured sum. As for livestock insurance, the rates in question do not exceed $0,5 \%$ of the insured sum.

The bill also envisages some changes to tariff rates offered by insurance companies. If the rates exceed, respectively, $9 \%$, $12 \%$ and $15 \%$ of the crop insured sum against all types of risk, then the above-mentioned amounts of support apply. If the insured sum is exceeded in relation to livestock insurance, the support does not apply.

The support is not granted if the tariff rates set by insurance companies against one type of risk or against many selected types of risk exceed set insurance tariff rates specified under the Act. This regulation aims at extending the insurance cover of crop and, at the same time, reducing production risk.

There is a new solution which enables an agricultural producer to make an insurance contract covering one type of risk or many selected types of risk from the list set out by the legislator. The list of types of risk remains the same as under the existing Act. The legislator is trying to incentivize farmers to make so-called package agreements, which are supposed to cover a few types of risk selected by farmers. That is why, the bill increases the tariff rates from the level of 3,5\%, 5\% and $6 \%$ of the insured sum to $9 \%$, with the possibility to increase them to $12 \%$ and $15 \%$ in relation to crop on agricultural lands of 5 th and 6th class. The provision aims at incentivizing insurance companies to set tariff rates for risk packages at the level acceptable by agricultural producers and to take into account applicable tariff rates of risk packages. It is left to the farmer, however, to choose the cover relating to one or many types of risk.

Finally, it needs to be stressed that proposed amendments aim not only at giving better cover to the producer but ultimately, at reducing the public expenses on other forms of support relating to the losses in the production activity. Moreover, package insurance will help to reduce the premium price in comparison with the existing ones. A farmer, being able to take out insurance against the most common types of risk occurring in Poland, such as drought, will have the possibility to extend the cover to other forms of risk at much lower price.

\section{Conclusions}

Running a production activity in agriculture needs to be identified with running a farmer's household. They are strongly connected, which to some extent stresses the need to protect farmers both in the economic and social aspect. A significant role is played by risk management, which is a complex process and includes various elements. One of these elements is, definitely, a crop and livestock insurance contract.

What needs to be stressed while assessing the implementation of the EU solutions by the national legislator is that insurance is so far the only measure used in Poland. It results from, among other things, the lack of relevant regulations, which would allow applying other measures, namely mutual funds and price stabilisation instruments. As for the insurances, they differ in terms of the scope of events the results of which are covered by the subsidized contracts. The EU legislator envisages public support for negative effects of plant and animal diseases, pest infestation or environmental incidents. Polish regulations, however, do not include these events. The conclusion is, therefore, that the scope of support under the Act is narrower that the support under the EU law. On the other hand, what needs to be recognized as a positive solution is the package insurance. Whether the implementation of package insurance will incentivize farmers to make insurance contracts more often depends on farmers' attitude towards the risk management issue. In order to make them more effective it is necessary to change the way ad hoc support, which is the most commonly used by farmers, is applied. Ad hoc support should relate only to these events and their results which are not covered by the insurance but it requires the implementation of relevant legislative solution.

\section{Acknowledgement}

The article was prepared under the research grant OPUS No 2013/09/B/HS5/00683: Legal instruments of risk management in agriculture production, funded by the National Science Centre.

\section{References}

1. ACT of 23 April 1964 THE CIVIL CODE. Polish Journal of Law 1964, No. 16, item 93, with subsequent amendments.

2. ANTON J. 2015. Risk management in agriculture: What role for policy in the new Common Agricultural Policy? In: Research Handbook on EU Agriculture Law (Editor MCMAHON J. A., CARDWELL M. N.). Edward Elgar Publishing, Cheltenham. p. 62-85. ISBN 978-1-78195-461-4.

3. COMMUNICATION from the Commission to the Council of 9 March 2005 on risk and crisis management in agriculture. COM (2005) 74, 9 March 2005. [cit. 10.10.2012].

4. COUNCIL DECISION 2009/470/EC of 25 May 2009 on expenditure in the veterinary field. OJ L 155, 18.6.2009, p. 30-45.

5. COUNCIL DIRECTIVE 2000/29/EC of 8 May 2000 on protective measures against the introduction into the Community of organisms harmful to plants or plant products and against their spread within the Community. OJ L 169, 10.7.2000, p. 1.

6. COUNCIL REGULATION (EC) No 73/2009 of 19 January 2009 establishing common rules for direct support schemes for farmers under the common agricultural policy and establishing certain support schemes for farmers, amending Regulations (EC) No 1290/2005, (EC) No 247/2006, (EC) No $378 / 2007$ and repealing Regulation (EC) No 1782/2003. OJ L 30, 31.1.2009, p. 16.

7. EC 2001. Risk Management Tools for EU Agriculture. Working Document, Agriculture Directorate-General: Economic analyses, forward studies, evaluation, [online]. [cit. 2016.10.07]. Available at: http://ec.europa.eu/agriculture/publi/insurance/ text_en.pdf.

8. HAMULCZAK M. - STAŃKO S. 2008 (editors). Price risk management and the possibility to stabilize agricultural producers' income, Institute of Agricultural and Food Economics National Research Institute Warszawa. ISSN 2392-3458.

9. HARDAKER B. J. - HUIRNE R. B. M. - ANDERSON J. R. - LIEN G. 2004. Coping with Risk in Agriculture. CA BI Publishing, Wallingford, p. 1-332 ISBN 0-85199-831-3. 
10. JANOWICZ-LOMOTT M. - ŁYSKAWA K. 2009. Agricultural insurance subsidized by the state - Polish experience and EU recommendations - summary, Insurance News. No 2, p. 138 ISSN 0137-7264.

11. KACZAŁA M. - ŁYSKAWA K. 2008. Effective insurance in managing an agricultural farm. Insurance news. No $1 / 2$, p. 36. ISSN 0137-7264

12. KIMURA S. - ANTON J. - LETHI C. 2009. Managing Risk in Agriculture: A Holistic Approach. OECD. Paris.

13. KWIECIEŃ I. 2010. Insurance in risk management in business activity. C.H. Beck, Warszawa, p. 45. ISBN 978-83-255-14617.

14. LIPIŃSKA I. 2016. Crop and livestock insurance as production risk management instrument in Poland and the EU. In: Agrarian issue. Legal and economic questions. (Editor Litwiniuk P.), p. $217-233$.

15. ŁYSKAWA K. - ROJEWSKI K. 2015. Types of threats and risk in agricultural activity - especially in plant production. In: Plan production insurance in Poland. (Editor KACZAŁA M., ROJEWSKI K.), Poltext, Warszawa, p. 43.

16. MARTINEZ J. 2012. Risikomanagement im Agrarsektor Der Völker und europarechtliche Rahmen. In. FRENTRUP, M. - THEUVSEN L. - EMMANN C. H. Risikomanagement in Agrarhandel und Lebensmittelindustrie, Clenze: Agrimedia. p. 75-93. ISBN 978-3-86263-080-6.

17. MOŹDZIOCH M. - PLOCH A. 2010. Climatic changes and crop insurance. Insurance news. p. 133-150. ISSN 0137-7264.

18. MUßHOFF O. - HIRSCHAUER N. 2010. Modernes Agrarmanagement Vahlen. 4. Auflage. Munchien. ISBN 978-3-80063684-6.

19. NAWRACAŁA J. 2010. Commercial Insurance Law. Commentary on legal regulations on insurance market. Wolters Kluwer, Warszawa, vol. I, p. 1282.

20. OECD 2000. Income Risk Management in Agriculture. Paris.

21. OECD. 2001. Risk Management Tools for EU Agriculture. Working Document, Agriculture Directorate-General: Economic analyses, forward studies, evaluation, European Commission.

22. OLKIEWICZ A. 2015. Risk in agricultural activity and insurance instruments of reducing it. Annals of the Polish Association of Agricultural and Agribusiness Economists. Vol XVII, No
2, p. 176-182. ISSN 1508-3535.

23. ORLICKI M. 2011. Compulsory insurances, Wolters Kluwer, Warszawa, p. 155-176. ISBN 978-83-264-3553-9.

24. ORLICKI M. 2011. Insurance contract. In: Law of obligations - specific matters. (Editor PANOWICZ-LIPSKA J.) CH BECK Warszawa, p. 801-814. ISBN 978-83-255-2550-7.

25. Bill of amending the Act on Crop and Livestock Insurance and the Stamp Duty Act, Form 469, https://legislacja.rcl.gov.pl/projekt/12281402. [cit. 10.10.2012].

26. REGULATION (EU) No 1305/2013 of the European Parliament and of the Council of 17 December 2013 on support for rural development by the European Agricultural Fund for Rural Development (EAFRD) and repealing Council Regulation (EC) No 1698/2005. OJ L 347, 20.12.2013, p. 487-548

27. REGULATION (EU) No 1307/2013 of the European Parliament and of the Council of 17 December 2013 establishing rules for direct payments to farmers under support schemes within the framework of the Common Agricultural Policy and repealing Council Regulation (EC) No 637/2008 and Council Regulation (EC) No 73/2009. OJ L 347, 20.12.2013, p. 608

28. Regulation of the Council of Ministers of 30 November 2015 on the amount of premium subsidies for livestock insurance in 2016, Polish Journal of Law 2015, item 2024.

29. SZEKELY C. - PALINKAS P. 2009. Agricultural risk management in the European Union and USA. Studies in Agricultural Economics. No 109, p. 55-72. ISSN (electronic): 2063-0476

30. Act of 22 May 2003 on Compulsory Insurance, the Insurance Guarantee Fund and the Polish Motor Insurers' Bureau, Polish Journal of Law 2013, item 392 with latest amendments.

31. Act of 7 July 2005 on Crop and Livestock Insurance, Polish Journal of Law 2015, item 577

\section{Contact address/ Kontaktná adresa}

\section{Dr. Izabela Lipińska}

Commercial and Agricultural Law Division, Department of

Management and Law, Faculty of Economics and Social Sciences,

Poznań University of Life Sciences,

Wojska Polskiego 28, 62-090 Poznań, Poland,

e-mail: lipinska@up.poznan.pl 